\title{
Plectosporium tabacinum, a Pathogen of the Invasive Aquatic Weed Hydrilla verticillata in Florida
}

\author{
M. L. Smither-Kopperl, R. Charudattan, and R. D. Berger, Plant Pathology Department, University of Florida, \\ Gainesville 32611
}

\begin{abstract}
Smither-Kopperl, M. L., Charudattan, R., and Berger, R. D. 1999. Plectosporium tabacinum, a pathogen of the invasive aquatic weed Hydrilla verticillata in Florida. Plant Dis. 83:24-28.

Plectosporium tabacinum, the anamorph of Plectosphaerella cucumerina, was isolated in 1996 from Hydrilla verticillata (hydrilla), an invasive aquatic weed in Florida. P. tabacinum, applied as a suspension of conidia, was pathogenic to hydrilla shoots maintained in aqueous solutions in test tubes. Koch's postulates were fulfilled in several repeated experiments. Infected shoots became slightly chlorotic within $24 \mathrm{~h}$ after inoculation. Infected leaves remained intact and were supported by water pressure but collapsed upon removal from water. Histological studies of leaves stained with malachite green and acid fuchsin revealed fungal hyphae within plant cells. The disease developed over a range of temperatures from 15 to $30^{\circ} \mathrm{C}$. At $25^{\circ} \mathrm{C}$, symptoms were most severe in 5\% Hoagland's solution, followed by river water, deionized water, $0.5 \%$ Hoagland's, tap water, and spring water. Disease severity increased as inoculum concentration was increased from $10^{5}$ to $10^{7}$ conidia $\mathrm{ml}^{-1}$. This is the first report of $P$. tabacinum as a pathogen of hydrilla, a fully submerged aquatic plant species.
\end{abstract}

Additional keywords: biological control, submerged weed, underwater pathosystem

The submerged aquatic weed hydrilla (Hydrilla verticillata (L.f.) Royle; Hydrocharitaceae) is an exotic, invasive species that is a threat to freshwater resources in the United States. Hydrilla in Florida is male, dioecious, and clonal and is spread by vegetative propagules (14). The weed replaces native vegetation through aggressive competition and is expensive to control by traditional methods such as cutting and use of chemical herbicides. Biological control with plant pathogens and insects is an environmentally friendly and potentially cost-effective alternative to the traditional control methods (4).

Studies of biocontrol of hydrilla have focused on an isolate of Fusarium culmorum from Stratiotes aloides collected in the Netherlands (5-7) and Mycoleptodiscus terrestris isolated from Eurasian water milfoil (Myriophyllum spicatum) in the United States (18). Recently, 2,200 microorganisms were isolated from hydrilla, surrounding water, and sediment from lakes and ponds in Florida. A representative sample of fungi (272) and bacteria (78) was screened with hydrilla in a labo-

Corresponding author: M. L. Smither-Kopperl
E-mail: MLSK@gnv.ifas.ufl.edu

Publication R-06143 Florida Agricultural Experiment Station Journal Series.

Acceptance for publication 5 October 1998.

Publication no. D-1998-1117-02R

(C) 1999 The American Phytopathological Society ratory bioassay $(16,17)$. Seventeen fungal isolates were pathogenic to hydrilla, while the remainder were nonpathogenic (17). Pathogenic isolates included Botrytis sp., Cephalosporium spp., Curvularia sp., Fusarium culmorum, F. moniliform, and Phytophthora sp.

During our experiments, hydrilla shoots collected from a natural spring (Blue Springs) and maintained in a $5 \%$ Hoagland's solution became chlorotic and died within 2 weeks. Isolations were made from leaf tissue on solid media, and a fungus was recovered from almost $100 \%$ of chlorotic tissue. The fungus was later identified as Plectosporium tabacinum and shown to be pathogenic to hydrilla (19). Since the fungus was recovered from symptomatic tissues, it was hypothesized that it could be a pathogen of hydrilla. Therefore, the main objective of this research was to investigate the development of the disease on hydrilla. Other objectives were to evaluate the virulence of $P$. $t a b$ acinum to hydrilla under various conditions of water quality, inoculum concentration, and temperature, and to assess its potential as a biocontrol agent.

\section{MATERIALS AND METHODS}

Hydrilla. Apical portions of hydrilla shoots 15 to $20 \mathrm{~cm}$ long were collected as needed from the following north Florida locations: Blue Springs, near High Springs; Bivens Arm, Gainesville; and Orange Lake, Cross Creek. The hydrilla was transported to the laboratory in black plastic bags and then placed in tap water in black plastic tubs $(78 \times 70 \times 30 \mathrm{~cm})$. The containers with hydrilla were placed outside during the summer and moved to a plastic greenhouse $\left(25 \pm 3^{\circ} \mathrm{C}\right)$ during the winter months, when the night temperatures outside could fall below freezing.

Aqueous solutions. Spring water was collected from the Manatee Springs and river water from the Suwannee River, Chiefland, Florida. Chemical analysis of these solutions in comparison with tap water and Hoagland's solution is shown (Table 1).

Isolation. Isolations were made from leaf and stem tissues with symptoms of chlorosis and browning. The tissues were surface-disinfested in 5\% sodium hypochlorite for $2 \mathrm{~min}$, rinsed three times in sterile deionized (DI) water, and plated on Komada's medium (9) or potato dextrose agar (PDA) in petri plates. The plates were incubated at $25^{\circ} \mathrm{C}$ under diurnal light.

Production of inoculum. Conidia were obtained from cultures of $P$. tabacinum grown for 2 weeks on PDA in petri plates. The plates were placed at room temperature under diurnal light for spore production. Conidia were routinely collected from 2-week-old cultures when plates were flooded with 5\% Hoagland's solution $+0.1 \% \mathrm{KHCO}_{3}, \mathrm{pH} 7.5$ (referred to hereafter as Hoagland's+), scraped gently with a sterile rubber spatula to dislodge the spores, and filtered through four layers of cheesecloth. The number of conidia was determined using a hemacytometer and adjusted to the required concentration.

Microscopic examination. Disease development was followed by light microscopic examination of hydrilla leaves 1,4 , 8,16 , and $24 \mathrm{~h}$ after inoculation with conidia of $P$. tabacinum. The leaves were stained with a temporary stain consisting of $95 \%$ ethanol $(25 \mathrm{ml})$, malachite green $(0.25 \mathrm{~g})$, DI water $(75 \mathrm{ml})$, and acid fuch$\sin (0.05 \mathrm{~g})$. The components were added sequentially to a capped bottle, and the bottle was shaken after each addition. Individual leaves were stained for $15 \mathrm{~min}$, rinsed twice in acidified $95 \%$ ethanol, and mounted for microscopic examination in $50 \%$ glycerol. The leaf tissue stained green and fungal tissue red, which allowed rapid assessment of the extent of fungal invasion and disease progress. Since colors faded after a few hours, observations were made immediately. This histological study was repeated once. 
Pathogenicity tests. For pathogenicity tests, terminal shoots of hydrilla $(6 \mathrm{~cm})$ were each placed in a sterilized test tube ( $25 \mathrm{~mm}$ diameter by $150 \mathrm{~mm}$ length) containing $45 \mathrm{ml}$ of water or an aqueous solution, with the hydrilla submerged beneath the water surface. Volumes $(1 \mathrm{ml})$ of $P$. tabacinum at concentrations of $0,10^{7}$, and $10^{8}$ conidia $\mathrm{ml}^{-1}$ were applied as small droplets over the surface of the aqueous solution. The test tubes were left undisturbed overnight for the conidia to settle on the leaves (20). There were six replicates in an initial experiment and 10 replicates in later experiments. The plants were maintained with a 12-h day length under fluorescent lights $\left(35.3 \mathrm{E} \mathrm{m}^{-2} \mathrm{~s}^{1}\right)$ at $25^{\circ} \mathrm{C}$. After 21 days, the plants were rated for disease symptoms with the following scale: $1=$ healthy, $2=$ up to $25 \%$ of the shoot area chlorotic, $3=26$ to $50 \%$ chlorosis, $4=$ 51 to $75 \%$ chlorosis, and $5=76$ to $100 \%$ chlorosis and death.

Reisolations were made from 10 leaves of each hydrilla shoot. The shoots were surface-sterilized by immersing in 5\% sodium hypochlorite for $2 \mathrm{~min}$ and rinsed three times in DI water. The leaves were detached from the stem and plated on Komada's medium (9). The plates were maintained under diurnal light at $25^{\circ} \mathrm{C}$ for 5 days and examined microscopically, and the number of leaves from which $P$. $t a b$ acinum grew was recorded. Hyphal tips were transferred to PDA for reisolation of the fungus in pure culture.

The effects of aqueous solution, inoculum concentration, and temperature on disease development on hydrilla caused by $P$. tabacinum were investigated. The effects of aqueous solutions on disease development were investigated in DI water, tap water, 5\% Hoagland's+, $0.5 \%$ Hoagland's+, spring water, and river water, with $P$. tabacinum added at a concentration of $10^{7}$ conidia $\mathrm{ml}^{-1}$. This experiment was repeated twice and the data from all three experiments were analyzed together. The effect of inoculum concentration was tested at $0,10^{5}, 5 \times 10^{5}, 10^{6}, 5 \times 10^{6}$, and $10^{7}$ conidia $\mathrm{ml}^{-1}$ in $5 \%$ Hoagland's+ and $0.5 \%$ Hoagland's+. The experiment was repeated twice, and the data were pooled and analyzed together. The effect of temperature at $15,20,25$, and $30^{\circ} \mathrm{C}$ was determined in 5\% Hoagland's+ and $0.5 \%$ Hoagland's+, with controls and $P$. tab- acinum added at a concentration of $10^{7}$ conidia $\mathrm{ml}^{-1}$. The experiment was repeated once, and the data were combined and analyzed.

Statistical analyses. The data were analyzed by analysis of variance with the General Linear Models procedure of the Statistical Analysis System (SAS Institute, Cary, NC). As there were no significant variations among experiments or the experiment by treatment interactions, data from repeated experiments were pooled and analyzed together. The means were compared using the Tukey-Kramer test.

\section{RESULTS}

Identification and description of the fungus. The fungus produced copious amounts of one-septate conidia on PDA which measured 10 to $12 \mu \mathrm{m} \times 3$ to $4 \mu \mathrm{m}$ (Fig. 1A) on PDA. The colony characteristics were variable from whitish, creamy colored, to pale pink, often with a slimy appearance. Brown ascomata were produced infrequently on PDA (Fig. 1B). Asci were persistent at the base, and the ascospores were two celled. Identification of the fungus as Plectosporium tabacinum (van Beyma) Palm et al. was confirmed by Mary E. Palm (USDA, APHIS, Systematic Botany and Mycology Laboratory, Beltsville, MD). The fungus is maintained in the culture collection of R. Charudattan.

Pathogenicity and disease symptoms. Hydrilla shoots in 5\% Hoagland's+ and $0.5 \%$ Hoagland's+ developed disease symptoms when inoculated with $P$. tabacinum (Fig. 2). Leaves were supported by water pressure, but upon removal from water they were limp and flaccid. Microscopic examination confirmed that fungal hyphae had invaded the plant cells within $24 \mathrm{~h}$, causing collapse and disruption of the infected tissues (compare Fig. 3A and B). After 2 weeks, infected plants were chlorotic and dead. P. tabacinum was reisolated from $100 \%$ of the inoculated leaves in all pathogenicity tests.

P. tabacinum induced disease in hydrilla shoots in all aqueous solutions, and the effect of inoculation was significant $(P<$ $0.05)$. The effect of the aqueous solution was highly significant $(P<0.01)$, and there was a significant interaction due to the fungus and the aqueous solution $(P<0.05)$. The solution most conducive to disease development was 5\% Hoagland's+, and the level of disease was higher in river water than in spring water $(P<0.05)$ (Fig. 4).

Disease severity increased with inoculum concentration, and the highest levels of disease occurred in 5\% Hoagland's+ $(P$ $<0.05)$ at $5 \times 10^{6}$ and $10^{7}$ conidia per $\mathrm{ml}$ (Fig. 5). There was no interaction between inoculum concentration and the aqueous solutions. Also, there was no significant difference in the effect of temperature on disease development over the temperature range tested, 15 to $30^{\circ} \mathrm{C}$ (Fig. 6).

\section{DISCUSSION}

$P$. tabacinum was described as a new unispecific genus for Fusarium tabacinum, the anamorph of Plectosphaerella cucumerina, in 1995 (12). F. tabacinum is also synonymous with Cephalosporium tabacinum and Microdochium tabacinum. P. tabacinum has a worldwide distribution, and it is commonly isolated as a saprophyte from soils. There are scattered reports of its pathogenicity to a wide range of plants and to a crustacean (1). It is reported to cause diseases of cucurbits in the southeastern United States $(2,15)$, tomatoes in Australia (13), groundnuts in Nigeria (11), sunflower in Italy (24), and Sagittaria trifolia (arrowhead, a submerged and emergent aquatic plant) in South Korea (8). There is also one report of $F$. tabacinum as a gill parasite on crayfish, Austropotamobius pallipes, in England (1). This pattern of a worldwide distribution and a wide host range, including a crustacean, is similar to that of another Fusarium species, Fusarium solani $\mathrm{f}$. sp. pisi, the anamorph of Nectria haematococca mating population IV (23). Further research into strain specificity and pathogenicity determinants for $P$. tabacinum is clearly justified.

$P$. tabacinum isolated from hydrilla plants in Florida was pathogenic to hydrilla, and the disease severity varied with the type of aqueous solution in which the plant was grown and tested. We isolated $P$. tabacinum originally from asymptomatic field collected plants that developed disease symptoms upon transfer to a $5 \%$ Hoagland's+ solution. The fungus obviously can colonize the host as a saprophyte, and it is therefore considered to be an opportunistic pathogen.

$P$. tabacinum may be ubiquitous and weakly parasitic and may, under certain environmental conditions, become highly

Table 1. Chemical analysis of aqueous solutions

\begin{tabular}{|c|c|c|c|c|c|c|c|c|c|c|c|c|}
\hline & \multicolumn{12}{|c|}{ Concentration (mg/liter) ${ }^{\mathrm{a}}$} \\
\hline & pH & $\mathrm{NH}_{4}$ & $\mathrm{NO}_{3}$ & $\mathbf{P}$ & $\mathbf{K}$ & $\mathbf{C a}$ & Mg & $\mathrm{Fe}$ & $\mathrm{Na}$ & Cl & $\mathbf{S i}$ & TOC $^{b}$ \\
\hline Manatee Springs & 8.1 & 0.26 & 6.2 & 0.0 & 5.2 & 97.4 & 7.0 & 0.0 & 4.3 & 7.4 & 3.2 & 12.0 \\
\hline Suwannee River & 8.0 & 0.26 & 1.8 & 0.1 & 1.7 & 53.8 & 6.0 & 0.2 & 5.0 & 7.4 & 3.2 & 13.3 \\
\hline Tap water & 8.6 & 0.26 & 0.4 & 0.4 & 15.6 & 28.2 & 18.9 & 0.1 & 11.5 & 29.1 & 12.6 & $<2.0$ \\
\hline $5 \%$ Hoagland's+ & 7.5 & 0.52 & 36.2 & 14.9 & 506 & 1.8 & 0.7 & 0.1 & 7.3 & 0.7 & 8.7 & 34.1 \\
\hline
\end{tabular}

a Samples were analyzed by Analytical Research Laboratory, IFAS, University of Florida, Gainesville 32611.

b Total organic carbon was analyzed by Advanced Technologies and Testing Laboratories, Inc., 13305 Rachael Blvd., Copeland Industrial Park, Alachua, FL 32615. 
pathogenic to hydrilla. The environmental effect of water quality had a major impact on the development of disease symptoms. Disease symptoms were more severe in nutritionally rich 5\% Hoaglands+ solution and river water (Table 1).
The inoculum levels used in the pathogenicity tests were not unrealistic; similar levels of inoculum have been used in other pathosystems. Furthermore, the symptoms caused by $P$. tabacinum infection were shown to spread from a single infected hydrilla shoot throughout a population of hydrilla in aquarium tanks (21), suggesting an efficient mode of secondary infection.

Hydrilla is invasive by means of its prolific vegetative growth, and in Florida only the male dioecious plant is present (14).

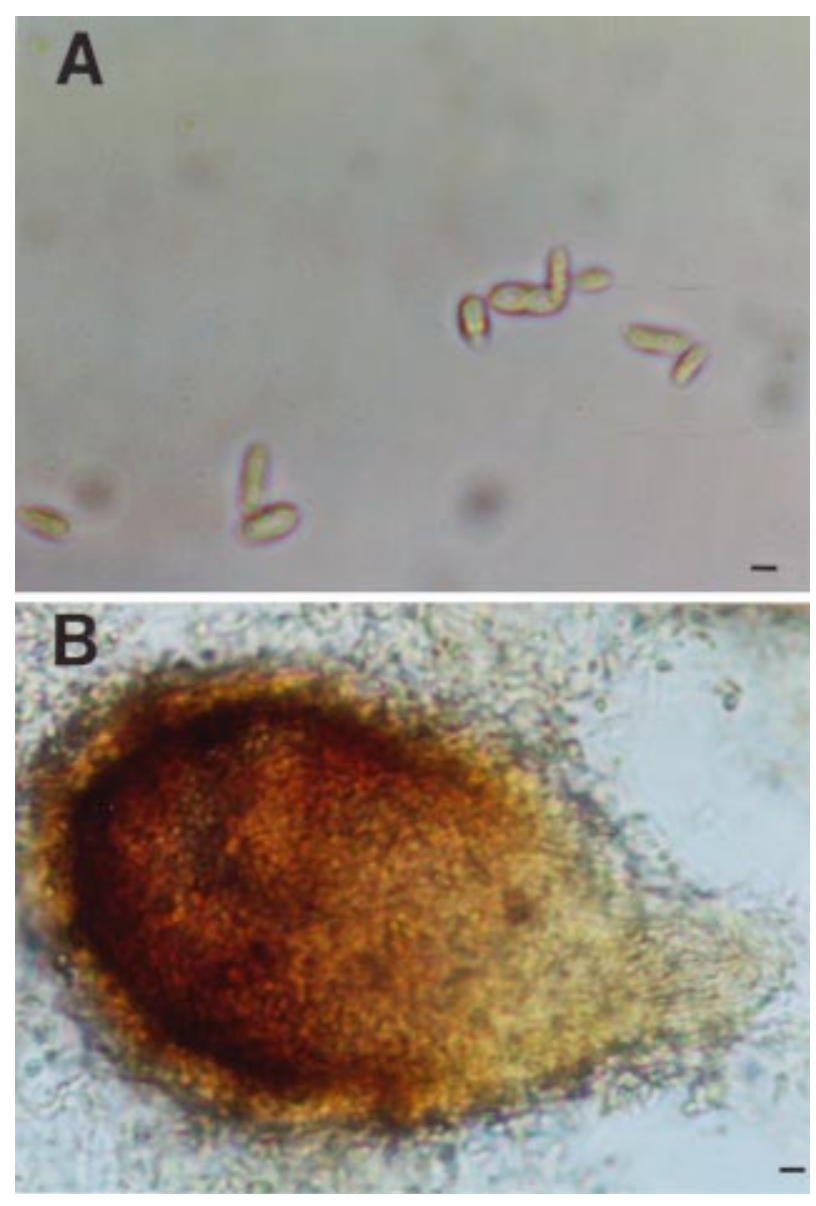

Fig. 1. Light micrographs of Plectosporium tabacinum, (A) conidia (bar $=5 \mu$ ), and $(\mathbf{B})$ perithecia $(b a r=10 \mu)$.

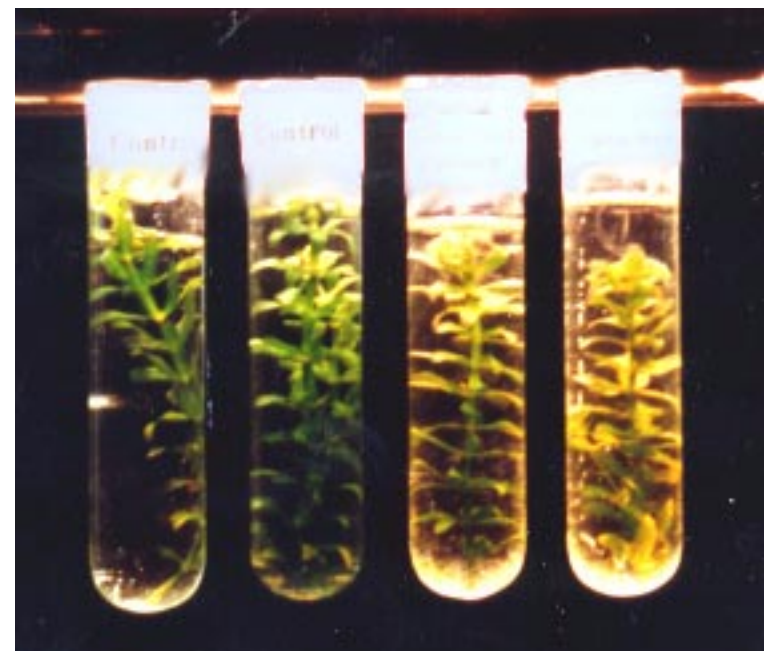

Fig. 2. Disease symptoms caused by Plectosporium tabacinum on hydrilla in test-tube assays. Controls are on the left, and hydrilla plants inoculated with $10^{7}$ conidia of P. tabacinum are on the right.
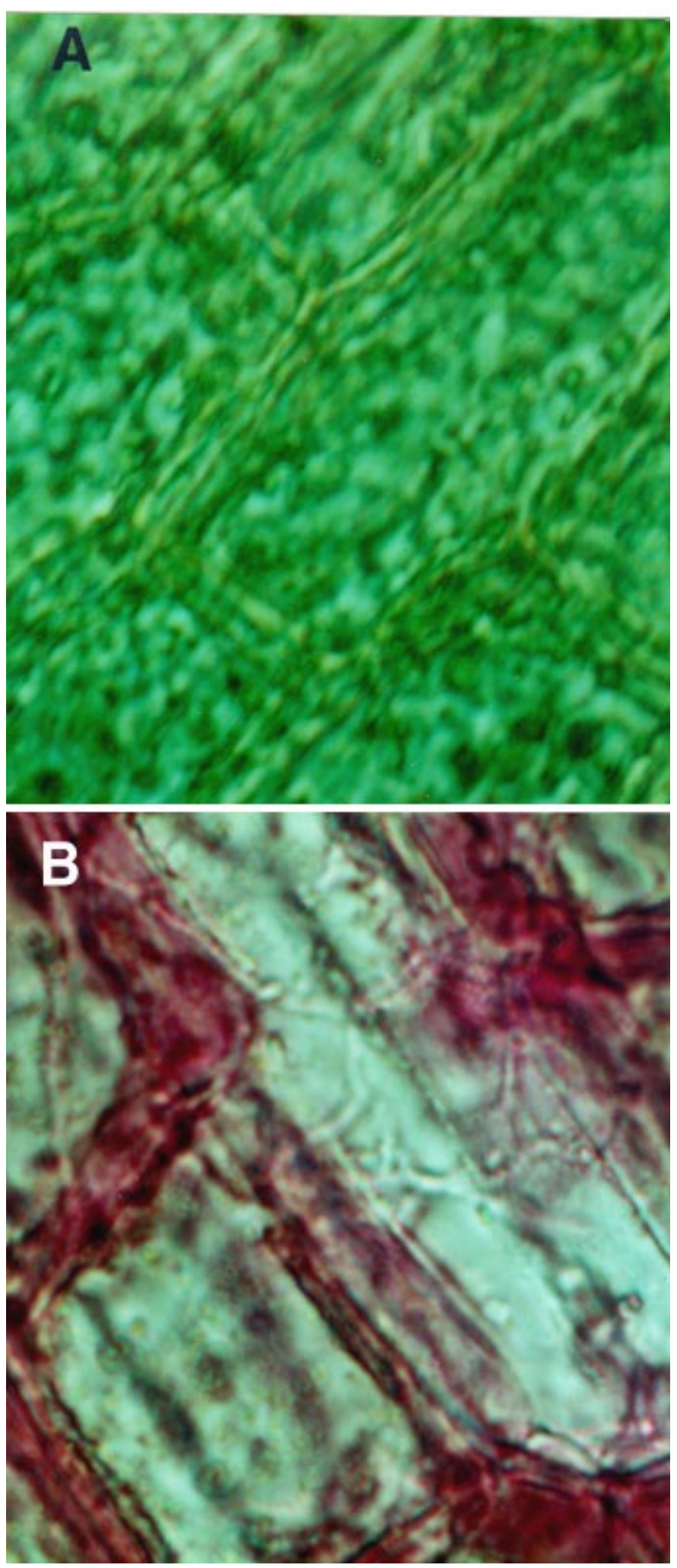

Fig. 3. Leaf cells of hydrilla, either (A) uninoculated or (B) $16 \mathrm{~h}$ after inoculation with Plectosporium tabacinum showing fungal hyphae entering the cells $(\times 400)$. 




Fig 4. Pathogenicity of Plectosporium tabacinum to hydrilla in aqueous solutions. Hydrilla shoots were established in $45 \mathrm{ml}$ of deionized water (DI), tap water (Tap), $0.5 \%$ Hoagland's $+0.1 \% \mathrm{KHCO}_{3}, \mathrm{pH} 7.5(0.5 \%$ $\mathrm{H}+), 5 \%$ Hoagland's+ $(5 \% \mathrm{H}+)$, spring water (Spring), and river water (River) in test tubes with plastic caps. P. tabacinum was applied at a concentration of $1 \times 10^{7}$ conidia ml ${ }^{-1}$ to the surface of the solutions. After 21 days, plants were rated for disease symptoms with a rating scale from $1=$ healthy to $5=76$ to $100 \%$ chlorosis and death.

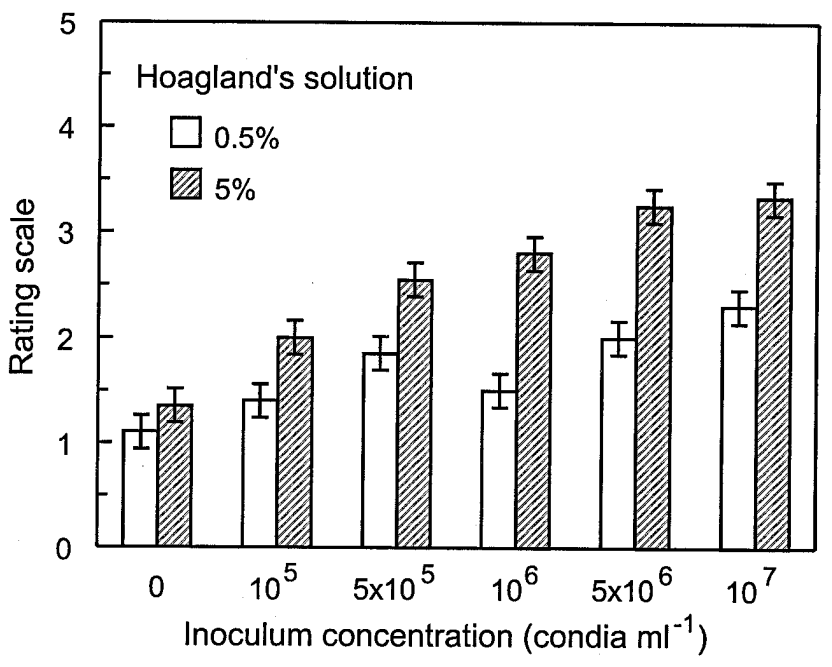

Fig. 5. The effect of inoculum concentration of Plectosporium tabacinum on disease severity in hydrilla. $P$. tabacinum was applied at concentrations of $0,10^{5}, 5 \times 10^{5}, 10^{6}, 5 \times 10^{6}$, and $10^{7}$ conidia $\mathrm{ml}^{-1}$ in Hoagland's $+0.1 \% \mathrm{KHCO}_{3}$, pH 7.5 (Hoagland's+) at $5 \%$ and $0.5 \%$. After 21 days, plants were rated for disease symptoms with a rating scale from $1=$ healthy to $5=76$ to $100 \%$ chlorosis and death.
This limits its genetic variability and therefore should reduce its ability to develop resistance to potential pathogens. In a survey of weeds effectively controlled by biological control, asexually reproducing species were more often controlled successfully than those that reproduced by sexual means (3). Thus, hydrilla should be an amenable target for biological control with fungal pathogens.

Low concentrations of chemical herbicides have been used in conjunction with fungal pathogens to induce diseases in aquatic weeds $(10,22)$. Integrated control of aquatic plants has been attempted by using the following combinations of chemical herbicides and fungal pathogens: fluridone and Mycoleptodiscus terrestris to control hydrilla (10), and endothall and Colletotrichum gloeosporioides for Eurasian water milfoil (22). This combination approach is most promising for long-term biocontrol of hydrilla, especially with pathogens such as $P$. tabacinum. This fungus has the capacity to colonize the plant as a saprophyte and to become a pathogen under favorable environmental conditions. It is therefore of potential importance as a biocontrol agent for use in an integrated control strategy for hydrilla.

\section{ACKNOWLEDGMENTS}

This research was supported by a USDACSREES-NRI Competitive Grant No. 95-373121656 and a Florida Department of Transportation, Environmental Management Office, Grant WI 0510742. We thank James Kimbrough and Mary E. Palm for assistance with identification, James T. DeVelario and Terri Davoli for technical assistance, and Jay Harrison for statistical advice. We also thank Dan E. Purcifull and David J. Mitchell for critically reviewing the paper.

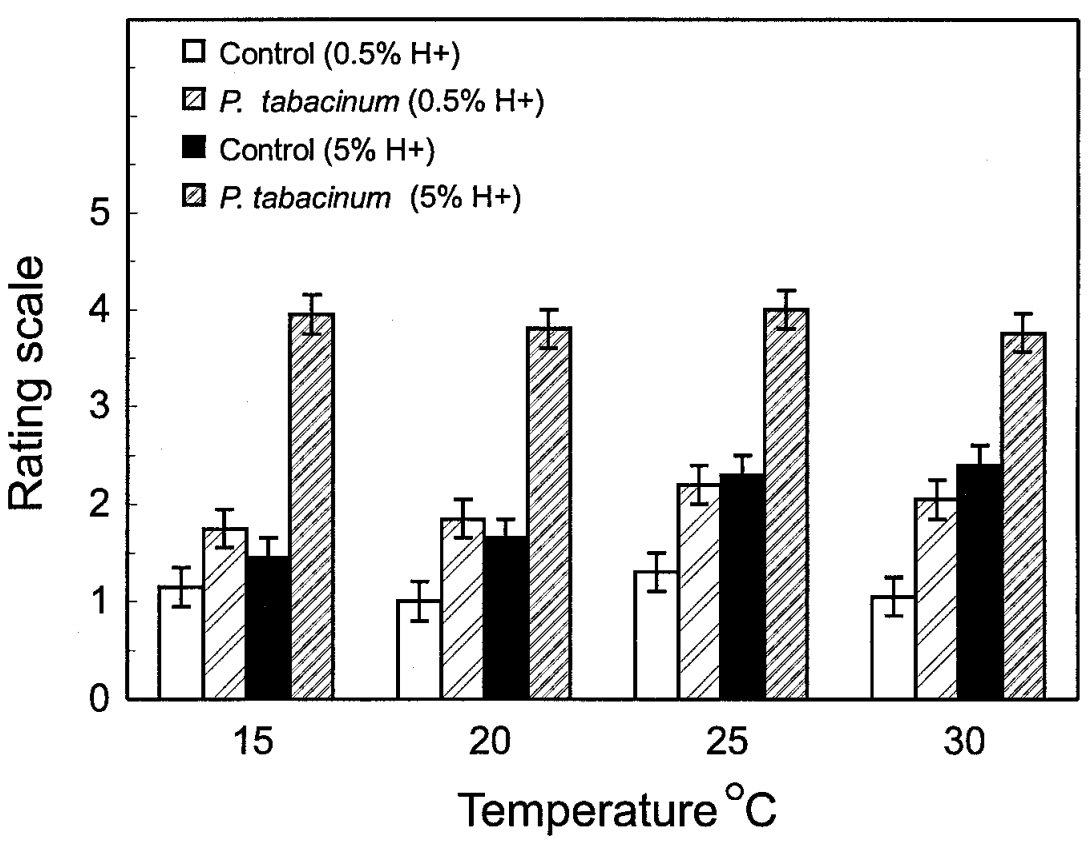

Fig. 6. The effect of temperature on development of disease caused by Plectosporium tabacinum on hydrilla. Hydrilla was grown in Hoagland's $+0.1 \% \mathrm{KHCO}_{3}, \mathrm{pH} 7.5$ (Hoagland's+) at either $5 \%$ or $0.5 \%$ at temperatures of $15,20,25$, and $30^{\circ} \mathrm{C}$ under diurnal light in growth chambers. P. tabacinum

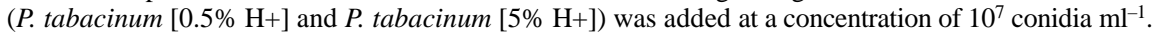
Controls were uninoculated $(0.5 \% \mathrm{H}+$ and $5 \% \mathrm{H}+)$. After 21 days, plants were rated for disease symptoms with a rating scale from $1=$ healthy to $5=76$ to $100 \%$ chlorosis and death.

\section{LITERATURE CITED}

1. Alderman, D. J., and Polglase, J. L. 1985. Fusarium tabacinum as a gill parasite in the crayfish, Austropotamobius pallipes. J. Fish Dis. 8:249-252.

2. Bost, S. C., and Mullins, C. A. 1992. A blight of cucurbits caused by Microdochium tabacinum. Plant Dis. 76:861.

3. Burdon, J. J., and Marshall, D. R. 1981. Biological control and the reproductive mode of weeds. J. Appl. Ecol. 18:649-658.
4. Charudattan, R. 1990. Biological control of aquatic weeds by means of fungi. Pages 186201 in: Aquatic Weeds: The Ecology and Management of Nuisance Aquatic Vegetation. A. H. Pieterse and K. J. Murphy, eds. Oxford University Press, New York.

5. Charudattan, R., Freeman, T. E., Cullen, R. E., and Hofmeister, F. M. 1980. Evaluation of Fusarium roseum "Culmorum" as a biological control agent for Hydrilla verticillata: Safety. Pages 307-323 in: Proc. V Int. Symp. Bio 
Control Weeds. E. S. Delfosse, ed. CSIRO Publ., Canberra, Australia.

6. Charudattan, R., and McKinney, D. E. 1977. A Fusarium disease of the submerged aquatic weed Hydrilla verticillata. Proc. Am. Phytopathol. Soc. 4:222.

7. Charudattan, R., and McKinney, D. E. 1978. A Dutch isolate of Fusarium roseum "Culmorum" may control Hydrilla verticillata in Florida. Proc. Eur. Weed Res. Soc. Symp. Aquatic Weeds 5:219-224.

8. Chung, Y. R., Koo, S. J., Kim, H. T., and Cho, K. Y. 1998. Potential of an indigenous fungus, Plectosporium tabacinum, as a mycoherbicide for control of arrowhead (Sagittaria trifolia). Plant Dis. 82:657-660.

9. Komada, H. 1975. Development of a selective medium for quantitative isolation of Fusarium oxysporum from natural soil. Rev. Plant Prot. Res. 8:114-125.

10. Netherland, M. D., and Shearer, J. F. 1996. Integrated use of fluridone and a fungal pathogen for control of hydrilla. J. Aquat. Plant Manage. 34:4-7.

11. Odundfa, S. A. 1979. Fusarium species associated with groundnut fruit and soil in Nige- ria. Trans. Br. Mycol. Soc. 72:342-344.

12. Palm, M. E., Gams, W., and Nirenberg, H. I 1995. Plectosporium, a new genus for Fusarium tabacinum, the anamorph of Plectosphaerella cucumerina. Mycologia 87:397406.

13. Pascoe, I. G., Nancarrow, R. J., and Copes, C. J. 1984. Fusarium tabacinum on tomato and other hosts in Australia. Trans. Br. Mycol. Soc. 83:343-345.

14. Pieterse, A. H. 1981. Hydrilla verticillata: A review. Abstr. Trop. Agric. 7:9-33.

15. Saad, A. T., and Black, L. L. 1981. A new fungus disease of cucurbits. (Abstr.) Phytopathology 71:902.

16. Shabana, Y. M., and Charudattan, R. 1996 Microorganisms associated with hydrilla in ponds and lakes in North Florida. J. Aquat. Plant Manage. 34:60-68.

17. Shabana, Y. M., Charudattan, R., and DeValerio, J. T. 1997. Herbicidal activity of microorganisms against hydrilla [Hydrilla verticillata (L.f.) Royle]. WSSA Abstr. 37:57.

18. Shearer, J. F. 1998. Biological control of hydrilla using an endemic fungal pathogen. J.
Aquat. Plant Manage. 36:54-56.

19. Smither-Kopperl, M. L., Charudattan, R., and Berger, R. D. 1997. Plectosporium tabacinum a pathogen of the aquatic weed Hydrilla verticillata in Florida. (Abstr.) Phytopathology 87:S92.

20. Smither-Kopperl, M. L., Charudattan, R., and Berger, R. D. 1998. Dispersal of spores of Fusarium culmorum in aquatic systems. Phytopathology 88:382-388.

21. Smither-Kopperl, M. L., Charudattan, R., and Berger, R. D. 1998. A model system to investigate the spread of Plectosporium tabacinum disease on hydrilla. (Abstr.) Phytopathology 88:S83

22. Sorsa, K. K., Nordheim, E. V., and Andrews, J. H. 1988. Integrated control of Eurasian water milfoil, Myriophyllum spicatum, by a fungal pathogen and a herbicide. J. Aquat. Plant Manage. 26:12-17.

23. Van Etten, H. D., and Kistler, H. C. 1988. Nectria haematococca, mating populations I and IV. Adv. Plant Pathol. 6:189-206.

24. Zazzerini, A., and Tosi, L. 1987. New sunflower disease caused by Fusarium tabacinum. Plant Dis. 71:1043-1044. 